Mawaddah, S., \& Tiyawati, S. (2021). Passive Smokers Pregnant Woment with Low Birth Weight. JURNAL INFO KESEHATAN, 19(1), 47-54.

Jurnal Info Kesehatan

Vol. 19, No. 1, June 2021, pp. 47-54

P-ISSN 0216-504X, E-ISSN 2620-536X

DOI: 10.31965/infokes.Vol19Iss1.299

Journal homepage:http://jurnal.poltekeskupang.ac.id/index.php/infokes

R E S E A R C H

\title{
Passive Smokers Pregnant Women with Low Birth Weight
}

\section{Sofia Mawaddah ${ }^{1 a^{*}}$, Sulis Tiyawati ${ }^{1 \mathrm{~b}}$}

${ }^{1}$ Department of Midwifery, Poltekkes Kemenkes Palangka Raya, Palangka Raya, Central Kalimantan, Indonesia.

${ }^{a}$ Email address: sofizline@gmail.com

b Email address: sulistiyawati@gmail.com

\begin{abstract}
The number of cases of low-birth-weight babies at dr. Doris Sylvanus Regional General Hospital, Palangka Raya in 2017 was as many as 378 cases. One of the causes of low birth weight was mothers who smoke actively or passively during pregnancy. The objective of this study is to determine the relationship between passive smoking pregnant women and the incidence of low birth weight at the dr. Doris Sylvanus Regional General Hospital, Palangka Raya. This research is an observational study using a cross-sectional research design and a retrospective approach with a sample of 45 mothers obtained using purposive sampling technique. Data analysis used Chi-Square statistical test. The results of the study found that pregnant women with heavy passive smokers gave birth to babies with low birth weight as many as 28 people $(62.2 \%)$ and 1 person who did not have low birth weight babies $(2.2 \%)$. Meanwhile, pregnant women with light passive smokers who gave birth to low birth weight were 12 people (26.7\%) and 4 people did not have low birth weight $(8.9 \%)$. Thus, there is a significant relationship between passive smoking pregnant women and the incidence of low birth weight at dr. Doris Sylvanus Regional General Hospital, Palangka Raya with $p=0.047$, $\mathrm{OR}=9.33$. For further researchers, it is recommended to examine the factors that cause pregnant women to smoke passively with the incidence of low-birth-weight babies.
\end{abstract}

Keywords: Pregnant Women, Passive Smokers, Low Birth Weight.

*Corresponding Author:

Sofia Mawaddah

Department of Midwifery, Poltekkes Kemenkes Palangka Raya, Palangka Raya, Central Kalimantan, Indonesia. Email: sofizline@gmail.com

(CThe Author(s) 2021. This article is distributed under the terms of the Creative Commons Attribution 4.0 International License (http://creativecommons.org/licenses/by/4.0/), which permits unrestricted use, distribution, and reproduction in any medium, provided you give appropriate credit to the original author(s) and the source, provide a link to the Creative Commons license, and indicate if changes were made. The Creative Commons Public Domain Dedication waiver (http://creativecommons.org/publicdomain/zero/1.0/) applies to the data made available in this article, unless otherwise stated. 


\section{INTRODUCTION}

Neonatals with complications are neonates with diseases and/or abnormalities that can cause disability and/or death, such as asphyxia, jaundice, hypothermia, neonatal tetanus, infection/sepsis, birth trauma, Low Birth Weight Babies (LBW), respiratory distress syndrome, and congenital abnormalities as well as those included in the yellow and red classification on examinations with the Integrated Management of Young Infants (Kementerian Kesehatan, R. I., 2016).

Low birth weight (LBW) is associated with increased morbidity and mortality in neonates. Premature birth also causes some complications, such as respiratory distress, feeding intolerance, or below-normal neurodevelopment compared to full-term babies. Many factors contribute to low birth weight and preterm birth, and one of the important factors is exposure to cigarettes, such as maternal smoking and exposure to secondhand smoke. Maternal active smoking during pregnancy causes decreased birth weight and significantly increases the risk of low birth weight. Decreased birth weight was discovered to be poorly correlated with maternal smoking rates during pregnancy (Ko, et al., 2014).

According to the World Health Organization (WHO), exposure to cigarette smoke in pregnancy is also associated with a risk of about $22 \%$ of babies being born with low birth weight $(<2500 \mathrm{~g})$ (World Health Organization, 2013). In Indonesia, the prevalence of men who smoke is around $67 \%$ and the prevalence of passive smokers who are exposed to secondhand smoke at home is around $78.4 \%$. Meanwhile, the prevalence of low birth weight in Indonesia based on the results of Basic Health Research 2013 is around 10.2\% (Kementerian Kesehatan, R. I., 2013).

However, the number of cases of low birth weight in Central Kalimantan in 2014 was 535 cases or $491.6 \%$ of the number of live births, an increase compared to 2015 as many as 556 cases or $1.2 \%$ of the number of live births (Dinas Kesehatan Provinsi Kalimantan Tengah, 2015). Meanwhile, the number of cases of babies with low birth weight at dr. Doris Sylvanus Regional General Hospital, Palangka Raya in 2016 as many as 378 cases and in 2017 as many as 332 cases (Rumah Sakit Umum Daerah dr. Doris Sylvanus, 2017).

One of the causes of low birth weight is mothers who smoke actively or passively during pregnancy. Research conducted by Titisari, (2011), discovered that pregnant women with passive smoking status have a significantly 5 times greater risk than pregnant women who are not passive smokers to give birth to low-birth-weight babies. Pregnant women who are exposed to cigarette smoke can adversely affect pregnancy and the fetus in the mother's womb. Chemical compounds contained in cigarettes can enter the body of a pregnant mother and poison the fetus.

Disruption of oxygen delivery to the fetus is the main cause of various adverse effects due to smoking in pregnant women. Pathological evaluation of the placentas of pregnant women who smoke demonstrates structural changes, including decreased capillary volume fraction and increased vitelline membrane immunity when compared to nonsmokers. Both of these factors may contribute to the abnormal gas exchange in the placenta. Acute exposure to cigarette smoke also reduces intervillous perfusion, possibly through nicotine-induced vasospasm (Bachok \& Salinah, 2014).

Passive smoking is a combination of side stream smoke that comes from the tip of a cigarette that is burned and mainstream smoke exhaled by smokers. Environmental Tobacco Smoke (ETS) is a carcinogen along with asbestos, benzene and radon gas (Goel, et al., 2004). Cigarettes contain nicotine which is a toxic chemical. In addition to nicotine, in cigarettes, there are also sugar compounds, additives, sauces, flavors, aromas, and others, so as to form a taste that meets the tastes of consumers (smokers). 
Nicotine can cause addiction in both active and passive smokers. Exposure to carbon monoxide from smoking causes the formation of carboxyhemoglobin, which has multiple effects on both systemic and fetal oxygen delivery. Nicotine exposure to the fetus results in sympathetic activation that causes an accelerated fetal heart rate and decreased fetal respiration. Human infants who have significant nicotine levels at birth have a limited ability to maximize heart rate during the first hour of life (Bachok \& Salinah, 2014). The objective of this study is to determine the relationship of passive smoking pregnant women with the incidence of low-birth-weight babies at dr. Doris Sylvanus Regional General Hospital, Palangka Raya.

\section{RESEARCH METHOD}

This research is an analytic observational study with a Cross Sectional approach. This research has been conducted at dr. Doris Sylvanus Regional General Hospital, Palangka Raya and performed in July - September 2018. The sample in this study were 45 pregnant women who were taken using the Purposive Sampling technique.

The instruments used in this study were interviews and fill-in formats. Data on the frequency of mothers exposed to cigarette smoke were obtained through interviews with mothers using data collection forms and data on the number of babies with low birth weight were known from the register book of the perinatology room at the dr. Doris Sylvanus Regional General Hospital, Palangka Raya.

The data analysis technique in this study used univariate analysis and bivariate analysis using the Chi-Square statistical test. To determine the odds ratio (OR) with 95\% confidential interval (CI), it employed the risk test. This research has also received ethical approval by the Health Research Ethics Commission of the Health Polytechnic of the Ministry of Health of Palangka Raya with Number: 02 B/XI/KE.PE/2018.

\section{RESULTS AND DISCUSSION}

Table 1. Frequency Distribution of Respondents.

\begin{tabular}{lrr}
\hline Variable & $\begin{array}{r}\text { Frequency } \\
\text { (n) }\end{array}$ & $\begin{array}{r}\text { Percentage } \\
\text { (\%) }\end{array}$ \\
\hline Baby Birth Weight & 40 & 88,9 \\
$<2500$ gram & 5 & 11,1 \\
$>2500$ gram & 16 & 35,6 \\
Status of passive smoking mothers & 29 & 64,4 \\
Moderate & & \\
Severe & 3 & 6,7 \\
Age of passive smoking mothers & 41 & 91,1 \\
$<20$ years old & 1 & 2,2 \\
20-35 years old & & 28,9 \\
>35 years & 13 & 68,9 \\
Parity of passive smoking mothers & 31 & 2,2 \\
Primipara & 1 & 2,2 \\
Multipara & & 4,4 \\
Grandemultipara & 1 & 40,0 \\
Complications during pregnancy & 2 & \\
Severe anemia & 18 & \\
Antepartum hemorrhage & & \\
Severe Preeclampsia & & \\
\end{tabular}


Premature Rupture of Amniotic fluid

Education of passive smoking mothers

Elementary School

Junior High School

Senior High School

University

Passive smoking mother's occupation

Housewife

Private employees

Civil Servant

Smoker family income

Low

Medium

High

Very high

Based on table 1, it is known that the most birth weights were $<2500$ grams as many as 40 babies (88.9\%). The status of mothers who were heavy passive smokers was 29 mothers $(64.4 \%)$. The most passive smoking mothers were $20-35$ years old with 41 mothers $(91.1 \%)$. The highest parity of smoking mothers was multiparous with 31 mothers $(68.9 \%)$. The highest number of complications during pregnancy was premature rupture of membranes with 24 cases. The highest education of passive smoking mothers was high school with 17 mothers $(37.8 \%)$. The occupation of the most mothers, which was Housewives amounted to 36 mothers $(80 \%)$ and the status of the highest family income, that was low income, amounted to 7 families (60.6\%).

Table 2. Relationship of Pregnant Women with Passive Smokers with Low-BirthWeight Babies.

\begin{tabular}{|c|c|c|c|c|c|c|c|c|}
\hline \multirow{2}{*}{$\begin{array}{l}\text { Passive } \\
\text { Smoking } \\
\text { Mothers }\end{array}$} & \multicolumn{4}{|c|}{ BBLR } & \multirow[b]{2}{*}{ Total } & \multirow[b]{2}{*}{$\%$} & \multirow[b]{2}{*}{ P Value } & \multirow[b]{2}{*}{ OR } \\
\hline & Yes & $\%$ & No & $\%$ & & & & \\
\hline Heavy & 28 & 62,2 & 1 & 2,2 & 29 & 64,4 & & \\
\hline Light & 12 & 26,7 & 4 & 8,9 & 16 & 35,6 & 0,047 & 9,33 \\
\hline Total & 40 & 88,9 & 5 & 11,1 & 45 & 100 & & \\
\hline
\end{tabular}

Based on table 2, it is presented the results of pregnant women with heavy passive smokers giving birth to babies with low birth weight as many as 28 mothers $(62.2 \%)$ and those who did not have low birth weight as many as 1 mother $(2.2 \%)$. Meanwhile, pregnant women with light passive smokers who gave birth to babies with low birth weight were 12 mothers (26.7\%) and 4 mothers did not have low birth weight (8.9\%). The results of statistical tests that obtained a significant value of 0.047 . Therefore, the $p$ value was $<0.05$. It shows that there is a significant relationship between passive smoking pregnant women and the incidence of low birth weight at dr. Doris Sylvanus Regional General Hospital, Palangka Raya and the results of statistical calculations also obtained an OR number of $p$-value $=9.33(95 \% \mathrm{CI})$.

Birth of low birth weight in passive smoking mothers is caused by continuous exposure to carbon monoxide (CO) during pregnancy. Carbon monoxide $(\mathrm{CO})$ can be bound in the mother's hemoglobin, resulting in decreased oxygen-carrying capacity (O2) in the mother's blood and in the end the fetus's body will receive less oxygen. In addition to carbon monoxide (CO), nicotine produced from cigarette smoke from active smokers and then inhaled by pregnant women can also reduce placental perfusion. 
The results of research conducted by Rufaridah, (2012), showed that pregnant women with passive smokers had 7.06 times the possibility of giving birth to babies with low birth weight compared to pregnant women who were not passive smokers. Nicotine is a vasoconstrictor. Thus, it constricts the blood vessels of the placenta and smoke increases the viscosity of the blood, making the blood a little thicker, thereby further impeding blood flow. Smoke from cigarette burning can enter through the placenta which increases the risk of low birth weight. The impact of the influence of these substances is below normal fetal growth.

Research conducted by Irnawati, (2011), showed that $90 \%$ of the most common sources of exposure to cigarette smoke for pregnant women were family members who smoked at home. The results of research conducted by Nurjanah, et al., (2014), showed that the factors associated with low birth weight are the duration of exposure to cigarette smoke in pregnant women in a day or per day. The results of research conducted by Noraini, et al., (2015), in Denpasar revealed that exposure to cigarette smoke in the house increases the risk of premature birth in Denpasar City.

Pramono and Muzakkiroh (2011), with measurements of continine levels (primary nicotine metabolism) found to be $80 \%$ in passive smokers. Meanwhile, in the Ramadhan research, (2012), 57\% of women exposed to cigarette smoke gave birth to babies with low body weight.

Research conducted by Chelchowska, (2013), stated that pregnant women with passive smoking status had a significantly 5 times greater risk than pregnant women who were not passive smokers to give birth to low-birth-weight babies. The results of research conducted by Rasyid, (2012), showed that there were 3 variables that were important determinants of the risk of giving birth to babies with low birth weight and one of the variables was exposure to cigarette smoke. Hence, the incidence of babies with low birth weights was 4.2 times greater compared to unexposed mothers.

The results of research conducted by Ko, et al., (2014), found that all groups of mothers who smoked had a higher incidence of low birth weight and premature birth, particularly if the mother smoked $>20$ cigarettes/day. Mothers who smoke are responsible for the increased incidence of low birth weight and therefore, smoking cessation or reduction should be advised to pregnant women to reduce morbidity in their neonates.

This study is not in line with research conducted by Zulardi, (2014), which stated that the highest incidence of low birth weight was in mothers aged $<20$ years or more than 35 years. Pregnancy over 35 years of reproductive organs is less fertile and increases the risk of birth with congenital abnormalities and is at risk for premature birth. A good age for pregnant women is 20-35 years. Babies born prematurely are also due to the mother's age being too young or too old, for young people less than 20 years old and too old for over 35 years. The age factor can affect the condition of the cervix because it is too weak, thus, the baby is born prematurely.

Research conducted by Hanum and Wibowo, (2016), showed that of the 48 mothers in the high-risk age category, the majority gave birth to babies with low birth weight, that were 39 mothers $(81.25 \%)$. It is possible that pulmonary function impairment has not occurred so that smokers still do not feel the effects of cigarette smoke which results in smoking behavior being carried out and influencing people around to become passive smokers. However, with the increasing age, the possibility of pulmonary function abnormalities will be greater and receive longer exposure to pollutants, including exposure to other people's cigarette smoke. 
The results of research conducted by Takziah, et al., (2013), examined that the incidence of low birth weight was more common in risk parity mothers, while normal birth weight babies were more likely to be born to non-risk parity mothers. Hence, the more parity of the mother, the more the risk with the incidence of low birth weight. Grandemultipara pregnancy causes a decline in the flexural power (elasticity) of tissues that have been repeatedly stretched by pregnancy, Thus, it tends to arise abnormalities in the location or abnormalities of placental growth and fetal growth so that they give birth to babies with low birth weight. It can affect the supply of nutrients from the mother to the fetus and the higher the parity, the higher the risk of giving birth to a baby with low birth weight.

The causes of low-birth-weight babies are generally multifactorial, one of which is maternal factors who experience complications during pregnancy such as severe anemia, antepartum bleeding, hypertension, severe preeclampsia, urinary tract infection (UTI) and premature rupture of membranes, and also socio-economic factors, culture related to education level, mother's occupation, and family economy. Education will indirectly affect the outcome of a pregnancy, especially the incidence of babies with low birth weight. It is related to the mother's knowledge in maintaining the condition of pregnancy as well as efforts to get service and health checks during pregnancy (Proverawati \& Ismawati, 2010).

The results of this study show that not only mothers with low education give birth to babies with low birth weight, but also mothers with higher education are still at risk of giving birth to babies with low birth weight. Similar to the results of research conducted by Irnawati, et al., (2011), mothers who have an education level of Elementary School are 1.6 times more likely to give birth to babies with low birth weight compared to mothers who have an education level of Junior High School.

In Indonesia, which is a developing country, the prevalence of people exposed to secondhand smoke is very high due to the high prevalence of smokers. The low level of awareness of a person and the weak enforcement of non-smoking area regulations cause the prevalence of active and passive smoking in Indonesia to continue to increase from year to year. Zuladri's research, (2014), showed that pregnant women with moderate smoking environments had a 3.25 greater risk of giving birth to babies with low birth weight than pregnant women with light smokers.

\section{CONCLUSION}

Based on the results of the study above, it shows that there is a significant relationship between passive smoking pregnant women and the incidence of low birth weight at dr. Doris Sylvanus Regional General Hospital, Palangka Raya with $p=0.047$, $\mathrm{OR}=9.33$. For further researchers, it is recommended to examine the factors that cause passive smoking pregnant women with the incidence of low-birth-weight babies.

\section{REFERENCES}

Bachok, N. A., \& Salinah, O. (2014). The effect of second-hand smoke exposure during pregnancy on the newborn weight in Malaysia. The Malaysian Journal of Medical Sciences: MJMS, 21(2), 44-53.

Chelchowska, M., Ambroszkiewicz, J., Jablonka-Salach, K., Gajewska, J., Maciejewski, T. M., Bulska, E., ... \& Leibschang, J. (2013). Tobacco smoke exposure during pregnancy increases maternal blood lead levels affecting neonate birth weight. Biological Trace Element Research,155(2), 169-175. doi: https://doi.org/10.1007/s12011-013-9775-8 
Dinas Kesehatan Provinsi Kalimantan Tengah. (2015). Profil Kesehatan Provinsi Kalimantan Tengah Tahun 2015. Palangka Raya: Dinas Kesehatan Provinsi Kalimantan Tengah.

Goel, P., Radotra, A., Singh, I., Aggarwal, A., \& Dua, D. (2004). Effects of passive smoking on outcome in pregnancy. Journal of postgraduate medicine, 50(1), 1216.

Hanum, H., \& Wibowo, A. (2016). Pengaruh paparan asap rokok lingkungan pada ibu hamil terhadap kejadian berat bayi lahir rendah. Jurnal Majority, 5(5), 22-26.

Irnawati, I., Hakimi, M., \& Wibowo, T. (2011). Ibu hamil perokok pasif sebagai faktor risiko bayi berat lahir rendah. Jurnal Gizi Klinik Indonesia, 8(2), 54-59. doi: http://dx.doi.org/10.22146/ijcn.17769

Kementerian Kesehatan, R. I. (2013). Riset Kesehatan Dasar Tahun 2013. Jakarta: Badan Penelitian dan Pengembangan Kementerian Kesehatan Republik Indonesia.

Kementerian Kesehatan, R. I. (2016). Profil Kesehatan Indonesia Tahun 2015. Jakarta: Kementerian Kesehatan Republik Indonesia.

Ko, T. J., Tsai, L. Y., Chu, L. C., Yeh, S. J., Leung, C., Chen, C. Y., ... \& Hsieh, W. S. (2014). Parental smoking during pregnancy and its association with low birth weight, small for gestational age, and preterm birth offspring: a birth cohort study. Pediatrics \& Neonatology, 55(1), 20-27. doi: https://doi.org/10.1016/j.pedneo.2013.05.005

Noriani, N. K., Putra, I. A. E., \& Karmaya, M. (2015). Paparan asap rokok dalam rumah terhadap risiko peningkatan kelahiran bayi prematur di kota denpasar. Public Health and Preventive Medicine Archive, 3(1), 68-73.

Nurjanah, N., Kresnowati, L., \& Mufid, A. (2014). Gangguan Fungsi Paru Dan Kadar Cotinine Pada Urin Karyawan Yang Terpapar Asap Rokok Orang Lain. KEMAS: Jurnal Kesehatan Masyarakat, 10(1), 43-52.

Proverawati, A., \& Ismawati, C. (2010). BBLR (Berat Badan Lahir Rendah). Yogyakarta: Nuha Medika.

Pramono, M. S., \& Muzakkiroh, U. (2011). Pola Kejadian Bayi Berat Lahir Rendah Dan Faktor Yang Memengaruhinya Di Indonesia Tahun 2010. Buletin Penelitian Sistem Kesehatan, 14(3), 209-17.

Ramadhan, N. (2012). Hubungan ibu hamil perokok pasif dengan kejadian bayi berat lahir rendah di badan layanan umum daerah RSU Meuraxa Banda Aceh. Jurnal Ilmiah STIKES U'Budiyah, 1(2). 27-34.

Rasyid, P. S. (2012). Faktor Risiko Kejadian Bayi Berat Lahir Rendah Di RSUD Prof. Dr. H. Aloei Saboe Kota Gorontalo Provinsi Gorontalo Tahun 2012. Thesis. Makassar: Universitas Hassanuddin.

Rufaridah, A. (2012). Pengaruh perokok pasif terhadap plasenta, berat badan lahir, apgar score bayi baru lahir pada ibu hamil di Kabupaten Padang Pariaman Tahun 2011. Thesis. Padang: Program Studi Ilmu Biomedik Universitas Andalas.

Rumah Sakit Umum Daerah dr. Doris Sylvanus Palangka Raya. (2017). Profil RSUD dr. Doris Sylvanus Palangka Raya 2017. Palangka Raya: Rumah Sakit Umum Daerah dr. Doris Sylvanus Palangka Raya.

Tazkiah, M., Wahyuni, C. U., \& Martini, S. (2013). Determinan epidemiologi kejadian BBLR pada daerah endemis malaria di Kabupaten Banjar Provinsi Kalimantan Selatan. Jurnal Berkala Epidemiologi, 1(2), 266-276. 
Titisari, B. R. (2011). Hubungan Ibu Hamil Sebagai Perokok Pasif dengan Bayi Berat Badan Lahir Rendah di Surakarta. Skripsi. Surakarta: Fakultas Kedokteran, Universitas Sebelas Maret.

World Health Organization. (2013). WHO recommendations for the prevention and management of tobacco use and second-hand smoke exposure in pregnancy. Geneva: World Health Organization.

Zulardi, A. R. (2014). Hubungan Lingkungan Perokok dengan Ibu Hamil Terpapar Asap Rokok terhadap Kejadian Bayi Berat Lahir Rendah di Surakarta. Skripsi. Surakarta: Fakultas Kedoteran, Universitas Surakarta. 